\title{
METHODS OF CONSENSUS BUILDING FOR COMMUNITY BASED FISHERIES MANAGEMENT IN BANGLADESH AND THE MEKONG DELTA
}

Parvin Sultana and Paul Thompson

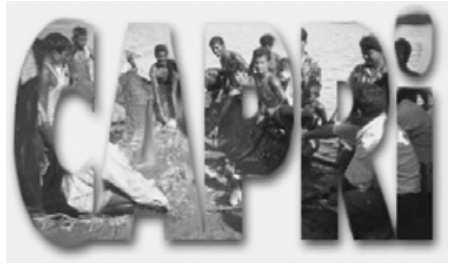

CGIAR Systemwide Program on Collective Action and Property Rights

\section{Secretariat:}

\section{International Food Policy Research Institute} 2033 K Street, N.W. Washington, D.C. 20006 U.S.A.
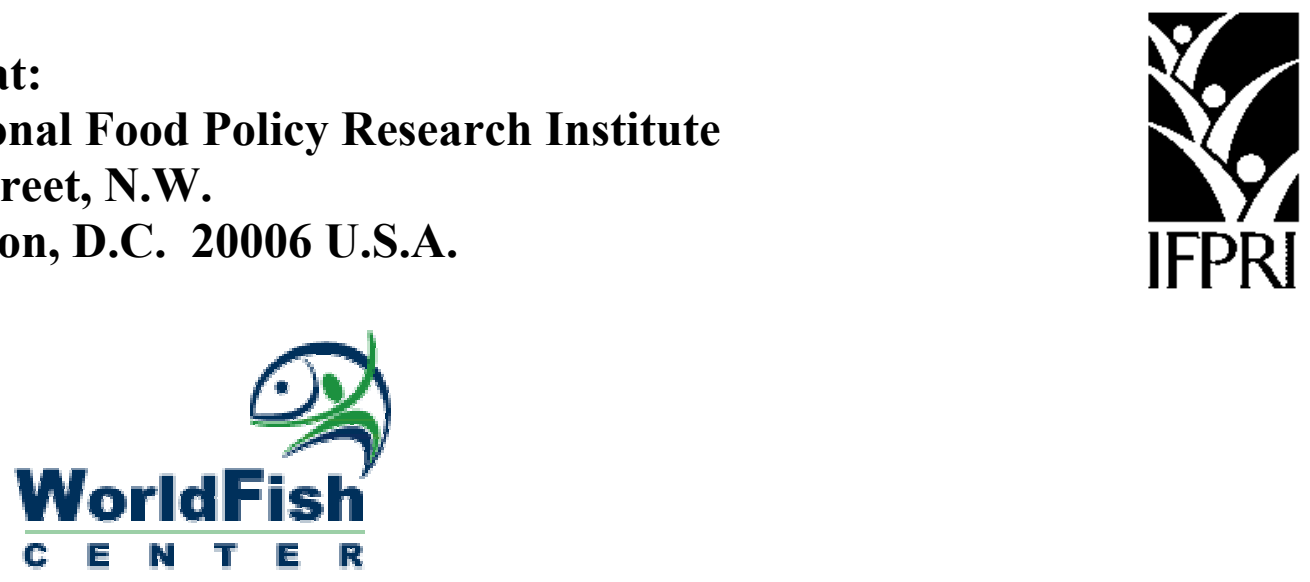

people - science - environment - parthera

May 2003

All CAPRi Working Papers are available for download from the CAPRi web site at http://www.capri.cgiar.org.

The CAPRi Program is one of several Inter-Center Initiatives of the CGIAR and aims to promote comparative research on the role played by property and collective action institutions in shaping the efficiency, sustainability, and equity components of natural resource systems.

CAPRi Working Papers contain preliminary material and research results, and are circulated prior to a full peer review in order to stimulate discussion and critical comment. It is expected that most Working Papers will eventually be published in some other form, and that their content may also be revised. 


\begin{abstract}
A method of consensus building for management of wetlands and fisheries using a systematic approach to participatory planning and initially developed in Bangladesh is now being applied in both Bangladesh and the Mekong delta. The method recognizes diversity in livelihoods and works through a structured learning and planning process that focuses on common interests. It works with each category of stakeholder separately to prioritize the natural resource problems that their livelihoods are largely dependent on, they then share and agree common priorities in plenary. Then the stakeholder groups separately analyze possible solutions and their impacts, before meeting in plenary to share their analysis and form a consensus on winwin solutions. The process identifies the collective actions that are needed to arrive at preferred solutions, and determines potential impacts on different stakeholders and responsibilities for implementation, monitoring and evaluation. We outline the process in the context of building social capital through consensus, and compare indicators of social capital as an outcome of its application in a Vietnamese village in the Mekong delta with the outcomes of a similar process in a floodplain wetland in Bangladesh.
\end{abstract}

KEYWORDS: Bangladesh; Vietnam; action research; consensus building; participatory process; collective action; social capital; wetlands; natural resource management 


\title{
METHODS OF CONSENSUS BUILDING FOR COMMUNITY BASED FISHERIES MANAGEMENT IN BANGLADESH AND THE MEKONG DELTA ${ }^{1}$
}

\author{
Parvin Sultana $^{2}$ and Paul Thompson ${ }^{3}$
}

\section{INTRODUCTION}

Community based management of natural resources or common pool resources has become a common strategy for improving resource management and empowering local communities in the past two decades based on concepts such as co-management, using local knowledge, recognizing local institutions and establishing common property regimes (Berkes et al. 1989; Ostrom 1990; Pomeroy and Berkes 1997). Although there has been a focus on design principles for community management institutions (Ostrom 1994) and on identifying factors linked with sustainable common property regimes and institutions (Agarwal 2001), there is also a question of how best to initiate such regimes and what participatory planning methods to use.

Efforts to improve management of inland fisheries through community

participation in Bangladesh have shown that some form of common property regime and facilitated local institution building are essential (Middendorp et al. 1999; Thompson et

\footnotetext{
${ }^{1}$ An earlier version of this paper was presented at a CGIAR System-wide Program on Collective Action and Property Rights (CAPRi) sponsored workshop on Methods for Studying Collective Action, Nyeri, Kenya, 25 February to 1 March 2002. The PAPD approach was initially developed by Center for Natural Resources Studies, Bangladesh and Newcastle University, UK. It was then refined and systematically tested by the same partners and WorldFish Center (formerly International Center for Living Aquatic Resources Management - ICLARM) in a UK DFID supported research project (R7562) in Bangladesh led by Julian Barr. It was then adapted and tested in the Mekong Delta of Vietnam by WorldFish Center and Can Tho University, with support from Oxfam America. We are grateful to all of these organizations and partners for their active participation in this process, and to the communities of Kathuria Beel and An Binh village. We are also grateful to Carol Colfer, Ruth Meinzen-Dick, Monica Di Gregorio and the participants of the CAPRi sponsored workshop for their comments and suggestions. This document is in part an output from a project funded by the UK Department for International Development (DFID) for the benefit of developing countries. The views expressed are not necessarily those of DFID.

${ }^{2}$ WorldFish Center, Batu Maung, 11960 Bayan Lepas, Penang, Malaysia

${ }^{3}$ WorldFish Center, House 22B Road 7, Banani, Dhaka, Bangladesh
} 
al. 1999, 2001). The two wetland case studies (Bangladesh and Vietnam) investigated in this paper relate to policies for devolving formally recognized rights over state-owned waterbodies to user groups, and enhancing and building informal community rights over common pool fisheries on seasonally flooded private land. In both cases it was found that a wider measure of participation and consensus among the full range of local stakeholders was sometimes lacking and this limited success. Floodplain wetlands have diverse uses - including agriculture, fisheries, irrigation, harvesting of wild plants (used for food, fodder, fuel, construction, and medicines) and other aquatic animals (e.g. snails for feeding ducks or humans), transportion, etc. Members of the user communities have similarly diversified livelihood strategies, but tend to specialize according to their assets, opportunities and skills. Some uses are complementary, being dependent on uncultivated wetland areas in the dry season; others are competing - for example drainage for agriculture.

The projects reported here aimed to develop and test a methodology for building consensus among stakeholders for sustainable management of common pool resources (particularly inland fisheries and aquatic resources). Consensus building is expected to identify win-win options, that take into account the interests of different stakeholders, and if implemented would improve the condition of the resource base and lives of users. The methodology developed for consensus building has been named Participatory Action Plan Development (PAPD) and involves holding a series of linked local workshops where different stakeholders in a wetland or fishery participate separately and in plenary to develop a management plan for the common aquatic resources they use (Barr et al. 2001). The original method was developed by a Bangladesh NGO, the Center for Natural 
Resource Studies and a team from Newcastle and Durham Universities. It can be characterized as deliberative, inclusive, and participatory (Holmes and Scoones 2000) and is designed to encourage participants to express their views, while avoiding a process that is dominated by locally powerful and vocal people, and to develop a shared framework of understanding about resource management. It is based on certain principles identified by Edmunds and Wollenberg (2001) in approaches to multi-stakeholder negotiations, such as the desirability of consensus, the need for all stakeholders to be involved in the process, neutrality, and the sharing of information. However, it does not focus on negotiation or resolving existing direct conflicts between two parties over resources and it is not appropriate in those situations. Of course competing interests in natural resource use exist and become clear during the process, but PAPD focuses on problems, needs, and potential solutions that are shared, and the differences and similarities in views of stakeholder groups over them. It is also adaptive and entails negotiations and conflict resolution activities (discussed later) in later stages to help achieve wider common aims and needs, and hence fits within the range of good practice identified by Edmunds and Wollenberg (2001).

The key features of the method are:

- to work with each category of stakeholders separately to identify and rank their problems regarding natural resource management (NRM), and for all stakeholder groups jointly to agree on the priority problems.

- for the stakeholder groups separately to analyze possible solutions and their impacts, before meeting in plenary to share their analysis and form a consensus on win-win solutions and actions,

- preparing in more detail an action plan for natural resources management. This paper summarizes the rationale of the approach adopted, outlines the process and method as it was developed and evolved in two different floodplain areas in 
Bangladesh and Vietnam, and assesses briefly the outcomes for social capital in these two applications. The research team undertook formal before-after/with-without interview surveys to assess changes in social capital and attitudes to the consensus building process. The larger study in Bangladesh is reported in detail in Barr and Dixon (2001), but there was not yet scope for detailed planning and implementation of the plans with the stakeholders. This raised questions over the extent that the process really achieved full consensus among different interest groups and how possible conflicts regarding plan implementation might be resolved, and these concerns were addressed when adapting the method in the second application in Vietnam.

\section{BUILDING CONSENSUS AND SOCIAL CAPITAL}

The PAPD method was designed to address the need, revealed by systems research on the floodplain (Barr 1998), for a more holistic approach to floodplain resource management, that is based on two principles:

1. Heterogeneity of different socio-economic groups pursuing different livelihood strategies. PAPD recognizes that primary stakeholders are not a homogeneous group and have diverse resource use patterns, production activities, and livelihood strategies, which may impinge on one another. The approach promotes recognition of the concerns of all stakeholders in floodplain resource use.

2. Inclusivity of all representatives of the different floodplain stakeholder groups in the planning process. Since the objective of the process is the identification of interventions to improve floodplain resource management that are acceptable to all resource users, it is important that the perspectives of the different groups be explored and taken into account in a 'shared-learning' process. 
The process recognizes that some groups, given their education, connections and social structures are more likely to be heard. PAPD therefore is designed to enable the voices of the disadvantaged and less powerful to be also heard. It also recognizes and takes into account 'secondary' stakeholders such as government agencies who have an interest in floodplain natural resource uses and their potential impacts. Many methods such as Participatory Rural Appraisal (PRA) aim to raise individual awareness of resource management problems; PAPD as a process raises collective awareness of the problems and leads towards collective action that can tackle them effectively. This is based on joint learning about resource-livelihood interdependence aimed at finding improved resource management solutions and establishing more participatory local institutional arrangements.

Measurement of the outcomes of such a process is part of the process itself. Potential outcomes include: improved understanding of participants about one another's livelihoods and use of aquatic resources, increased awareness of the issues in management of aquatic resources and possible improvements, agreements over management of these resources, greater social equity, and ultimately the different actions adopted. In the long term measurable improvements in biodiversity, fish populations, production, and people's livelihoods, status and empowerment could be hoped for and need to be assessed against their initial situation.

Possible indicators and approaches for assessing the impact of the consensus building process included the extent that it:

- changes the level of cognitive social capital, 
- enhances trust and reciprocity (potentially assessed through economic investment games and experiments),

- is an empowering process (qualitative assessment of criteria related to process),

- is inclusive/representational,

- focuses on common issues/goals,

- follows principles of civil discourse (openness; all can speak),

- adapts and incorporates high quality information (aware of the science),

- encourages challenging assumptions,

- maintains the interest of participants,

- ensures that consensus is sought only after full exploration of the issues,

- results in a decline in reported conflict (e.g. stealing/poisoning fishes), though this makes the assumption that conflict is the antithesis of consensus, which is not clearly established, and

- makes use of methods from Alternative Dispute Resolution (ADR) - these are more conflict focused, and more focused on outcomes.

One approach for assessing impacts of the PAPD process is to use the sustainable livelihoods framework (Carney 1998) and to focus on measuring changes in social capital - in broad terms the networks, relationships, values and attitudes that make and position a community. Krishna and Shrader (1999) use a conceptual framework that separates micro- and macro-levels of social capital. The macro-level relates to the institutional context in which organizations operate. Two types of micro-level social capital were the basis for understanding consensus building in this study:

- Structural social capital includes the composition and practices of formal and informal local institutions that serve as instruments of community development. Following Bain and Hicks (1998), Krishna and Shrader (1999: 10) state that 'Structural social capital is built through horizontal organizations and networks that have collective and transparent decision making processes, accountable 
leaders, and practices of collective action and mutual responsibility.' Structural social capital enables groups or communities to take collective actions through established roles and social networks, supplemented by rules, procedures and precedents (Krishna and Uphoff 1999).

- Cognitive social capital refers to values, beliefs, attitudes, and social norms that predispose people and communities towards collective action. 'Values' includes co-operation and 'the trust, solidarity and reciprocity that are shared among members of a community and that create the conditions under which communities can work together for a common good' (Krishna and Shrader 1999: 10).

Krishna and Uphoff (1999: 7) state that cognitive and structural social capital are interactive and mutually reinforcing, but they distinguish between them as follows: structural social capital is relatively objective; it includes things that are visible or tangible, and can be devised through group deliberation. It is external as it can be observed and directly modified. 'Cognitive social capital is essentially subjective, being a matter of how people think and feel.' It is internal, residing within peoples' heads, and not easily changed by external intervention.

Assessing structural social capital is closer to monitoring physical and organizational outcomes of consensus building efforts. These could not arise within the short term covered in the case studies presented here although they are expected to develop over a longer period and this will be monitored. Therefore in the concluding part of this paper an attempt is made to assess changes in levels of cognitive social capital that might be associated with PAPD, recognizing that this is difficult to change but also that consensus building aims to change attitudes and values and to increase the likelihood of collective action. 


\section{PAPD METHODOLOGY}

As originally conceived, PAPD was seen as a two-stage process comprising a problem census (listing of problems and ranking of their importance by different stakeholder groups) followed by stakeholder and plenary planning workshops. However, through the process of applying and testing the PAPD process, it has evolved into three phases that lead into continual or long-term participatory resource management. Each phase has a number of different stages and activities, here we characterize thirteen different stages in the process based on the two applications discussed (Fig. 1). These comprise:

\section{Scoping phase (Stages one to three)}

1. Situational analysis (through summarizing local knowledge).

2. Stakeholder analysis (with help of key informants).

3. Household census and invitations to a random sample of households to PAPD (stratified by stakeholder categories).

II. Participatory planning phase (Stages four to eight)

4. Problem census (with each individual stakeholder group).

5. Compilation of problem rankings by facilitators (separating natural resources problems, combining stakeholder group rankings).

6. Plenary with stakeholder representatives and local leaders (to review problems, vote on the top three or four for solution analysis).

7. Solution and impact analysis (with each individual stakeholder group).

8. Plenary with stakeholder representatives and secondary stakeholders (to present the whole process, identify feasible solutions, discuss institutional arrangements proposed by separate groups and next step

III. Implementation (institution building, problem solving for individual stakeholders and resource management) phase (Stages nine to thirteen)

9. Develop and adapt community organizations and institutions for fishery/common pool resource management. 
10. Community organization develops detailed plan to implement solutions agreed in stage eight.

11. Review of plans by wider community and adjustments to plan (to mitigate or avoid any adverse impacts for example).

12. Implementation of action plan (for example, physical works, application of rules, monitoring).

13. Institutionalization of management arrangements including local policy support.

Fig. 1. The thirteen stages and three phases of the PAPD process.

Adapted and developed from Barr and Dixon (2001)

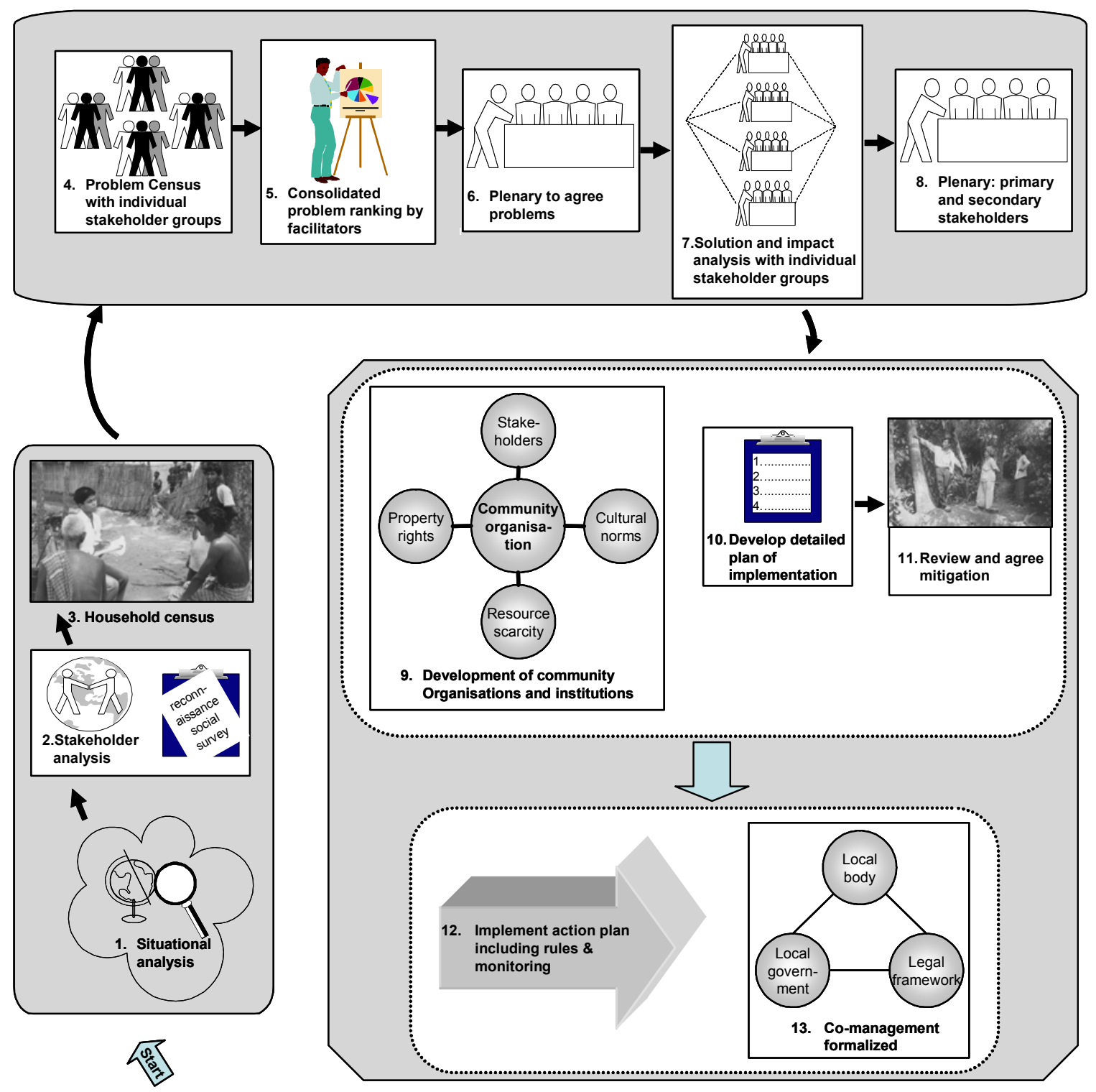


At the heart of the process are stages four to eight that involve participatory workshops with separate stakeholder groups and combined plenary sessions. These stages may be termed the PAPD proper and have been the main focus of the action-research on the method discussed in this paper, as it is here that the substantive consensus is built, but this should be seen as one important phase in a larger process. In the more general sense action research addressing problems of the community, has its focus on steps 9 through 13 where both institutional arrangements and fishery management actions are tested and evolve through the efforts of the community with advice and facilitation from NGOs, government agents and researchers.

A similar phased approach to community-based resource management has been developed elsewhere, for example Pomeroy (1998) with three phases for fisheries comanagement projects (Table 1) and Allen et al. (2001) with four steps in two phases for integrated systems of knowledge management in projects for animal pest control. Such phased processes appear to work both in research and participatory development. They involve an exploratory phase, an information sharing and mutual learning phase, and an action phase.

Table 1--Three phases of community-based resource management projects.

\begin{tabular}{lll}
\hline & Participatory Action Plan Development & \\
\hline 1. & Scoping & Fisheries co-management $^{\mathrm{b}}$ \\
& & Pre-implementation \\
2. & Participatory planning & Implementation \\
3. & Implementation / management & Phase-out / post-implementation \\
\hline
\end{tabular}

Sources: ${ }^{a}$ this study and ${ }^{\mathrm{b}}$ Pomeroy (1998)

Participatory planning as a process is often lost in the detail of tools and products (resource maps, calendars, diagrams, time lines, etc.). Such tools are essential to facilitators to understand different livelihood activities and their relation to resources and 
seasons, and give insight on trends in natural resource use and management. However, if participatory processes are to result in agreements for sustainable collective action by a range of diverse stakeholders, then the participants need to learn about each other and their different understandings of the environment. In PAPD, this mutual learning occurs in phase two.

In the following sections, the PAPD process and its evolution, in the Bangladesh and Vietnam case studies, is explained and reviewed.

In the Bangladesh site it was not possible to go beyond stage eight during the PAPD held in October 2000, although a separate project involving the same partners has, since 2001, been building on the earlier consensus and has now developed community institutions that have started to implement their plan.

In Vietnam the local government (the People's Organization for the concerned village) became directly involved in the PAPD process in November 2001, after capacity building and PRAs in the previous two to three years. It also provided funding, so the stakeholders followed through to prepare a detailed implementation design where they modified institutions to define each stakeholders' roles and responsibilities for improving resource management and participatory monitoring and research. They started the implementation of the plan in December 2001 (for example, setting rules for fish conservation and environmental management including sanctions for violators). Stages ten and eleven in the process arose here to bridge between institutional development and implementation. The individual interest groups reviewed the plans and households living next to the resources where physical interventions were planned raised issues of anticipated negative impacts from interventions or of specific rules. They started to 
disagree with the plan, and in response the research team facilitated meetings between each individual interest group and the hamlet leaders (government and non-government). Through one-to-one problem identification and alternate solution analysis on an individual basis it was possible to allay fears in some cases, and in other cases the People's Organization agreed alternative means of implementation to avoid conflicts or potential negative impacts. In this way the common consensus on benefits was retained and an ownership process even among people who were skeptical of the plan was builtin.

\section{PAPD IN APPLICATION}

\section{SCOPING PHASE, STAGE 1: SITUATIONAL ANALYSIS}

\section{General issues}

PAPD may be carried out in locations where the facilitating organization has already been working. This makes the scoping phase easier as the organization should have a good understanding of the biophysical, economic, social and cultural environment of the area. This was true in these two case studies, as Can Tho University in Vietnam and Banchte Sheka (a Bangladeshi NGO which focuses on empowering poor women), each working with the WorldFish Center, had already worked respectively in the Vietnam site in the Mekong Learning Initiative (MLI) and adjacent to the Bangladesh site in the first phase of the Community Based Fisheries Management (CBFM) project.

Where the facilitating organization does not have prior experience of the area, it needs to first acquire information about the communities, the natural resource systems and sub-systems, and the level of interaction between communities and resource systems. This has been termed 'situational analysis', it does not need to be a formal exercise but PRA tools such as participatory resource mapping are useful. It simply involves 
following good practice: speaking to a number of local key informants and triangulating what they say, visiting the area and observing systems of natural resource management. This provides the facilitators with insights that they can use during the PAPD workshops, when they try to draw out constraints and possible solutions. In practice further situational analysis was done in stage four of the PAPD process with each stakeholder group. This included drafting seasonal calendars to understand the relationships between livelihoods, seasonality of problems and impacts of possible solutions, and to chart key events to understand trends and changes affecting natural resources (see Table 2).

Table 2--Key events in An Binh, Vietnam in the past 25 years.

$1975 \quad$ Fish catches start declining

$1976 \quad$ Fish disease

1978 Cooperative movement, start to grow 2 crops a year, Flood, HYV variety, fish declined due to abstracting more water for irrigation

1979 Low yield of rice due to disease, deep flooding

1983-84 Introduced 3 crops/year

$1992 \quad$ First electricity in the village

1994-95 Outbreak of brown hopper (rice pest)

1996 First elementary school in the village

1997 Deep flooding $(1.7 \mathrm{~m})$

1998 Re-excavation of Nga ngay canal, bridge built over Ram Rau canal and road constructed along the Nga ngay canal

$2001 \quad$ Foot and mouth disease outbreak (affected pigs)

Application - the study sites

Kathuria Beel is a seasonal waterbody covering about 100 ha in southwestern Bangladesh. The waterbody has two parts - a low lying area of fields and fallow land which forms a seasonal wetland or beel (a beel is a depression in the floodplain) and an adjacent canal (khal). The beel is in one sub-district but the attached water control structure and canal are in another sub-district. Most of the users of Kathuria Beel live in five adjacent villages. Many individuals own the land in the beel area from these villages. The canal is state property and a project of the Local Government Engineering 
Department had been trying to establish a group to control the canal for water retention and aquaculture, but during the PAPD process it was found that most of the people living around the beel were strongly opposed to this initiative since only a few local leaders had been involved in its planning and aimed to take control of the water resources. During the rainy season the beel and the khal merge in one sheet of water and are a common fishery for all the residents of the area (although part of the area is cultivated with deepwater rice). At the end of the rainy season fish become trapped in the beel and in the khal and remain a common fishery, except that some water adjacent to individual homesteads is enclosed by bamboo fences to cultivate fish, and privately owned ditches in the beel are used as catch-ponds for private fishing. During the dry season the entire beel dries up and the land is all used for rice cultivation, with just a limited amount of water remaining in the khal and ditches. The khal was once re-excavated but now has silted up. A total of 887 households were present in the villages around this beel in 2000, most (76\%) were functionally landless or small farmers (under 0.6 ha of land). They fish in this beel and other similar adjoining beels.

In Vietnam, although the PAPD covered An Binh Village as a whole, it focused on Loi Du-B hamlet which is the lowest lying and most rural part of the village. This part of Can Tho Province is one of the most densely populated areas in the Mekong Delta and a majority of the population relies on aquatic resources for subsistence. The hamlet has a population of 2,984 people. Between 1997 and 1998, the population growth rate was 1.3 per cent, mainly from in-migration. Women residents (54 per cent) outnumber men in the hamlet, but men account for 80 per cent of the active labor force which is 30 per cent of the total population. There are 629 households of which 2 per cent are poor and landless. 
This hamlet is situated along the Rau Ram canal, which is connected to the Mekong by the Can Tho river. Because of the hamlet's proximity to the river system, its economic activities are interspersed with and highly dependent on the dynamics of the Mekong River. The river system provides access to very diverse aquatic resources that support the livelihood of the community, but problems in the Mekong River also negatively impact community members' well-being.

Loi Du-B hamlet has a land area of 162 ha, 97 per cent of which is devoted to agriculture. The main economic activity in the hamlet is farming, although households depend on fishing for daily subsistence and home consumption. Perennial crops such as banana and citrus are found in the orchards that occupy some 64 ha. The remaining 93 ha of agricultural area is characterized by a semi-deep water regime and almost all is planted to irrigated rice, allowing at least two rice crops a year and one cash crop such as maize.

SCOPING PHASE, STAGES TWO AND THREE: STAKEHOLDER ANALYSIS AND CENSUS

\section{Theory}

PAPD is fundamentally a stakeholder-based process. Initially, key informant discussions are used to identify the locally relevant stakeholder groups. This can be combined with the situational analysis. Given the importance of agriculture and natural resources to rural people's livelihoods, the stakeholder groups tend to be linked with the main resource use activities. However, socio-economic status and gender also need to be considered in making this categorization. Poor and landless women were identified as a stakeholder group in these two applications to ensure coverage of the livelihood problems of some of the most disadvantaged people on the floodplain. 
The census is designed to identify the stakeholder categories by incorporating locally relevant indicators of resource use and socio-economic status, such as ownership of a tube-well or type of fishing gear owned, as well as nationally relevant indicators such as land ownership. All households using the resource (based on identification of relevant settlements in the situation analysis) are included. The households are classified into locally appropriate stakeholder groups, but sufficient information is obtained to also classify them using national indicators for wider relevance of analysis. The scoping phase also builds rapport with communities in the area and builds awareness of the process at an early stage.

In a heterogeneous community where there is differentiation in livelihood assets, resource dependence, wealth and power, it is important that all different stakeholders are represented and participate. This is unlikely to occur through a passive approach, such as announcement of a village meeting. An active approach to participation of stakeholders is necessary to ensure that traditionally marginalized groups are represented ( $\mathrm{McCool}$ and Guthrie 2001). Therefore in stage three for each stakeholder category a random sample of households is drawn and the household representatives are then personally contacted and invited to participate in the PAPD.

\section{Application: census and participant selection}

Previous research in Bangladesh found size of landholding to be a functional indicator of socio-economic status (Barr et al. 2000). Principal occupation (for example fishing) was found to be an indicator of the major resource use activity for natural resource-dependent households. Therefore, following key informant discussions, in order to identify stakeholder categories a census of all households in the communities that included landholding size and principal occupation was undertaken. Table 3 shows the 
stakeholder categories used, the overall population, and sample sizes for PAPD. In Bangladesh kua (ditch) owners were identified as a special interest group during the situation analysis and scoping since they are landowners who also own ditches that they use as fish aggregating devices to catch a substantial part of the total fish catch from the beel. In Vietnam the community was less clearly differentiated and landholding size did not vary greatly, but whether the household had fish ponds, and/or an orchard was significant in its livelihood diversification.

Table 3--Categorization of households and samples involved in consensus building workshops in Bangladesh and Vietnam.

a) Kathuria Beel, Bangladesh

\begin{tabular}{|c|c|c|c|c|c|}
\hline Groups & Total HH & No participants & Groups & Total HH & No participants \\
\hline Fisher & $114(13 \%)$ & 17 & Landless & $512(17 \%)$ & 17 (10 women) \\
\hline Landless men & $151(17 \%)$ & 17 & Women dominated & $904(31 \%)$ & 30 (all women) \\
\hline Landless women & & 16 & Rice + orchard & $934(31 \%)$ & 31 (3 women) \\
\hline Small farmer & $403(46 \%)$ & 17 & Rice + orchard + fish & $632(21 \%)$ & 21 (5 women) \\
\hline Kua owner & $48(5 \%)$ & 17 & Total & 2982 & 99 \\
\hline Large farmer & $171(19 \%)$ & 16 & & & \\
\hline Total & 887 & 100 & & & \\
\hline
\end{tabular}

Notes: $\mathrm{HH}=$ households

In Bangladesh two samples were drawn from the landless households (one of men and one of women); "landless" was defined as owning up to 0.2 ha (0.5 acres) of land, marginal-small farmer own 0.2-0.6 ha (0.5-1.5 acres), and mediumlarge farmers own over 0.6 ha ( 1.5 acres).

In Vietnam "landless" was defined as only owning homestead land, women dominated households were those where women provide the main sources of household income.

Note that all participants in Bangladesh were men except for the landless women. In Vietnam, some of the farmers were women, and a majority of the landless households were represented by women in the PAPD because the men were working outside the area at that time. 
People were actively recruited to the PAPD. In Bangladesh a random sample of about eighteen households from each category and the respective men or women were individually informed and invited to the PAPD process (most accepted but a few refused and alternates were invited). In Vietnam all the households living next to the canal were included in the PAPD, along with random samples proportional to population from the rest of the village. The invited participants were also interviewed at that time using a questionnaire designed to assess various dimensions of their social capital, particularly as it related to common pool resources and collective action. In order for these largely resource poor households to participate without giving up opportunities to work, they were paid for each full day of the PAPD that they attended. The amount paid was equal to the local wage rate for daily labor.

\section{PARTICIPATORY PLANNING PHASE}

\section{Theory and design}

The participatory planning phase involves five stages that form a framework for stakeholders to formulate and develop a common understanding of their problems and potential solutions. Participants identify the constraints they experience for their livelihoods, particularly those related to natural resources, and share their views on how they may be overcome, especially through better resource management.

However there is a paradox in participation due to the inverse relationship between people's willingness to express their views frankly, and the number and diversity of people participating. Individuals are more likely to be willing to discuss issues freely on an individual basis than they may be willing to express themselves in public. Participatory planning is expected to be democratic and is typically portrayed as 
being neutral and fairly representing all people's views, yet it tends to occur in public forums that may be manipulated by more powerful individuals or stakeholder groups. It has been observed that public events tend to result in generalizations and a single 'ideal' view of interests and issues that may mask distinct and possibly conflicting interests (Mosse 1994), and that such compromises rarely meet everyone's objectives (Edmunds and Wollenberg 2001).

People may not contribute their ideas to a public discussion for several reasons. For example:

- they do not consider their ideas valuable,

- they do not want to upset the status quo,

- they want to avoid offending others at the meeting, and

- it is not traditionally or culturally accepted for them to speak in a public meeting (for example, women and young people) when it is for others (e.g. male elders).

The anthropological approach to obtain information of the real workings of society is to gradually build relations with a few key individuals who will often be forthcoming in a non-public forum. This can then be validated by triangulation with what other individuals say, but it is a slow process and involves no explicit public consultation or planning objective. Participatory planning therefore tends to result in 'democratic' outcomes based on generalities bounded by what is acceptable to discuss in public rather than the sum of individual views.

An alternative is for people to express their ideas in a less judgmental forum where they feel comfortable, for example with friends or people from similar backgrounds. Here they can express their real concerns rather than the perceived interests 
that these marginalized groups are usually accorded. The drawback is that these views are not aired in public and the diversity of views from different stakeholders does not contribute to shared understanding and mutual learning, and so there is no change in the status quo. The design issue for effective participatory planning is to balance the comfort of a closed forum of separate stakeholder groups where the real problems and issues are discussed and everyone contributes, with an open forum that may be dominated by a few vocal people or types of people and may only provide a platform for airing the same old issues, what Kaner (1996) called 'business as usual'.

For difficult and more complex problems, such as stakeholder opinions and options in fishery and wetland management, our experience is that open public meetings face precisely these problems. Kaner (1996) argued that to reach new collectively agreed solutions, participants must pass through three stages (Fig. 2). Firstly divergent ideas must be expressed, secondly stakeholders must participate in the process of trying to appreciate one another's perspectives - achieving a shared framework of understanding, and finally converging towards a closure zone or decision point. 
Fig. 2. Achieving balance through linked small group and plenary sessions.

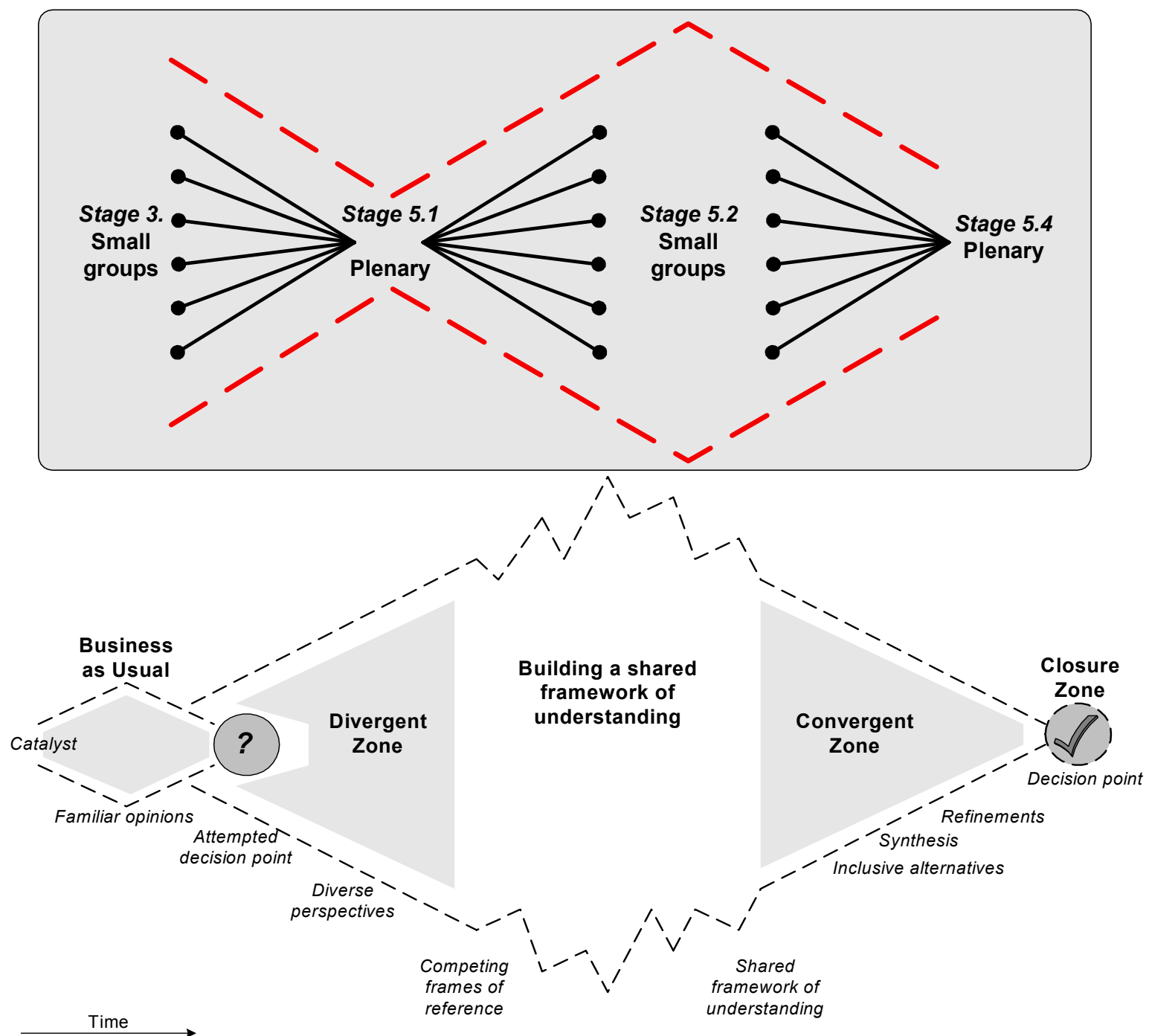

after Kaner (1996)

The PAPD method has been designed with this in mind. The objective is to encourage the frank expression of a full diversity of views on natural resource management and for a representative public voice to arise in the participant communities. No single activity, with small homogeneous groups or with larger community wide groups, will be able to achieve this, so the method aims to overcome this paradox of public and private voices through a series of linked separation and aggregation steps that 
together can result in a balanced view. The separation steps are exercises undertaken by stakeholder groups separately. The aggregation steps are facilitated plenary sessions where all groups are represented (Fig. 2). This has similarities with other approaches that have combined public meetings with individual interviews to bring diverse views into public negotiation, for example that of Ravnborg and Westermann (2000).

\section{APPLICATION}

In both case studies each stakeholder group spent a one day workshop on a problem census. They listed all their problems, discussed and agreed on some consolidation of their problems, then voted on their priority problems (each participant had five stickers to place against cards summarizing and illustrating the problem, the votes could be distributed among five or less problems according to each participant's individual assessment and priorities). Care was taken not to inadvertently influence the participants or the direction of the discussion, and this required good facilitation skills. Then the votes were summed and for the ten most important problems for the stakeholder group as a whole they analysed the causes and effects. In addition because it would be difficult to manage and coordinate plenary activities with all of the PAPD participants from each stakeholder group, at the end of the day each participant was asked to nominate the five other participants he or she would prefer as representatives from their group in the plenary, voting occurred individually in private, the votes were then summed and the most popular representatives were invited to attend the plenary.

The next stage was for the facilitators to consolidate and prioritize the problems identified by the different stakeholder groups. To limit potential facilitator biases in consolidation of problems across stakeholder groups, the method developed was to focus 
only on the top ten problems identified by each stakeholder group as ranked and then sum the scores across all groups to get an overall score and ranking. This was also done separately for the poorer stakeholder groups. Natural resource related problems were separated out from other development problems at this stage to give two rankings. In this way the overall priorities for natural resources issues/problems and other problems were ranked, and there was a check to ensure that the priorities of poorer people were included in the top 5-6 overall problems. Table 4 compares the problem rankings from both case studies and shows considerable similarities, although there was more direct concern for agricultural productivity in the Vietnam site probably because a higher percentage of the population are landowners.

\section{Table 4--Consolidated ranking of natural resource and other developmental} problems in two sites in Bangladesh and Vietnam.

\begin{tabular}{|c|c|c|c|c|}
\hline \multirow[t]{2}{*}{ Rank } & \multicolumn{2}{|c|}{ Natural resources related problems } & \multicolumn{2}{|c|}{ Other development related problems } \\
\hline & Bangladesh & Vietnam & Bangladesh & Vietnam \\
\hline 1 & $\begin{array}{l}\text { Sluice gate does not operate } \\
\text { properly }\end{array}$ & Natural fish declining & $\begin{array}{l}\text { Poor road } \\
\text { communication }\end{array}$ & Lack of capital \\
\hline 2 & $\begin{array}{l}\text { Canal connecting Kathuria } \\
\text { Beel with river has silted up }\end{array}$ & Siltation of canal & $\begin{array}{l}\text { Lack of safe drinking } \\
\text { water }\end{array}$ & $\begin{array}{l}\text { Poor road } \\
\text { communication }\end{array}$ \\
\hline 3 & Natural fish declining & $\begin{array}{l}\text { Water pollution / poor } \\
\text { drinking water }\end{array}$ & Lack of capital & Access to electricity \\
\hline 4 & Lack of unity & $\begin{array}{l}\text { Rice production } \\
\text { declining }\end{array}$ & No electricity & $\begin{array}{l}\text { Low price of } \\
\text { agricultural products }\end{array}$ \\
\hline 5 & $\begin{array}{l}\text { Low lying land is single } \\
\text { cropped }\end{array}$ & Flood & $\begin{array}{l}\text { Poor education } \\
\text { provisions }\end{array}$ & Local security \\
\hline 6 & $\begin{array}{l}\text { Lack of fishing gear (boats } \\
\text { and nets) }\end{array}$ & $\begin{array}{l}\text { Lack of modern }(\mathrm{HYV}) \\
\text { rice variety }\end{array}$ & Poor nutrition & Irrigation/drainage \\
\hline 7 & $\begin{array}{l}\text { Poaching by force by } \\
\text { outsiders }\end{array}$ & River bank erosion & Poor hygiene & Unemployment \\
\hline 8 & $\begin{array}{l}\text { Ditches in the beel have silted } \\
\text { up }\end{array}$ & Use of harmful gear & Poor health facility & Unstable rice price \\
\hline 9 & Fish diseases & & $\begin{array}{l}\text { Shortage/high price of } \\
\text { agricultural inputs }\end{array}$ & \\
\hline 10 & Scarcity of fish seed/fry & & Unemployment & \\
\hline 11 & Lack of cattle & & & \\
\hline 12 & $\begin{array}{l}\text { Use of harmful gear (current } \\
\text { net) }\end{array}$ & & & \\
\hline
\end{tabular}

Source: PAPD workshops. 
This analysis and the top five or six natural resource-related problems were reviewed and validated in the first plenary by representatives of each stakeholder group plus local leaders. Through small group discussions and rankings from all of these groups, the top three natural resources problems were identified and later presented for solution analysis and action planning. In addition the analysis made by each stakeholder group during the problem census was consolidated by the facilitators so that causes and effects for the main problems were on record, and those referring to the agreed priorities were presented in the plenary. Table 5 shows the outcome for the top three problems in the Vietnam site, which shows that causality is generally not a clear and simple linear relationship but a more complex linked problem tree.

Table 5--Example of consolidated problem analysis from Vietnam site.

\begin{tabular}{|c|c|c|c|c|}
\hline Problem & Causes & Effects & Solution & Affected \\
\hline $\begin{array}{l}\text { Fish } \\
\text { declining }\end{array}$ & $\begin{array}{l}\text { - Low water level, shallow canal } \\
\text { - High pesticide use } \\
\text { - Rice production throughout the year } \\
\text { changed fish habitat } \\
\text { - Electric fishing } \\
\text { - Use of duck to catch fish } \\
\text { - Over fishing } \\
\text { - Catching undersized fish }\end{array}$ & $\begin{array}{l}\text { - Less fish for } \\
\text { consumption and } \\
\text { sale }\end{array}$ & $\begin{array}{l}\text { - Fish conservation by } \\
\text { making a sanctuary } \\
\text { - Fish culture } \\
\text { - Strict regulation of use } \\
\text { of harmful gear and net } \\
\text { mesh size } \\
\text { Also see next two } \\
\text { problems }\end{array}$ & Community \\
\hline $\begin{array}{l}\text { Siltation of } \\
\text { canal }\end{array}$ & $\begin{array}{l}\text { - Canal was excavated in } 1998 \\
\text { - Bank erosion due to many engine boat } \\
\text { - Daily wave action brings more silt and } \\
\text { erodes banks }\end{array}$ & $\begin{array}{l}\text { - Fish declining } \\
\text { - Water transport } \\
\text { becomes difficult } \\
\text { during dry season }\end{array}$ & - Canal re-excavation & Community \\
\hline $\begin{array}{l}\text { Water } \\
\text { pollution }\end{array}$ & $\begin{array}{l}\text { - Low water flow in the canal } \\
\text { - Pig and poultry raising } \\
\text { - Waste from noodle industry } \\
\text { - Limited awareness about environment } \\
\text { - Use of pesticide } \\
\text { - Dam on the canal }\end{array}$ & $\begin{array}{l}\text { - Less fish } \\
\text { - Health problem } \\
\text { - Lack of safe } \\
\text { drinking water }\end{array}$ & $\begin{array}{l}\text { - Sink tubewell } \\
\text { - Excavation of canal } \\
\text { - Strict rule for waste } \\
\text { water } \\
\text { management/disposal } \\
\text { - Use filter for domestic } \\
\text { water } \\
\text { - Bigger diameter pipe } \\
\text { for drainage } \\
\text { - Limit use of pesticide }\end{array}$ & Community \\
\hline
\end{tabular}

Source: PAPD workshop

Following agreement on the priority problems in the first plenary, the separate stakeholder groups again met to each spend a day on solution analysis. Three activities 
are involved: firstly a stakeholder analysis including what is called a force-field analysis of all other stakeholders affecting the participant stakeholder or interest group's livelihoods. Fig. 3 shows an example from the Bangladesh site showing the stakeholders identified by landless women: along the horizontal line are those with a neutral effect; above are an inner circle of strongly positive influences (mostly providing work), and an outer circle of other positive influences; below the horizontal are negative influences who are mostly powerful and exploit the poor or represent authorities which limit their scope to improve their lives (fishers compete for fish).

Fig 3--Example of force field analysis by landless women in Bangladesh site

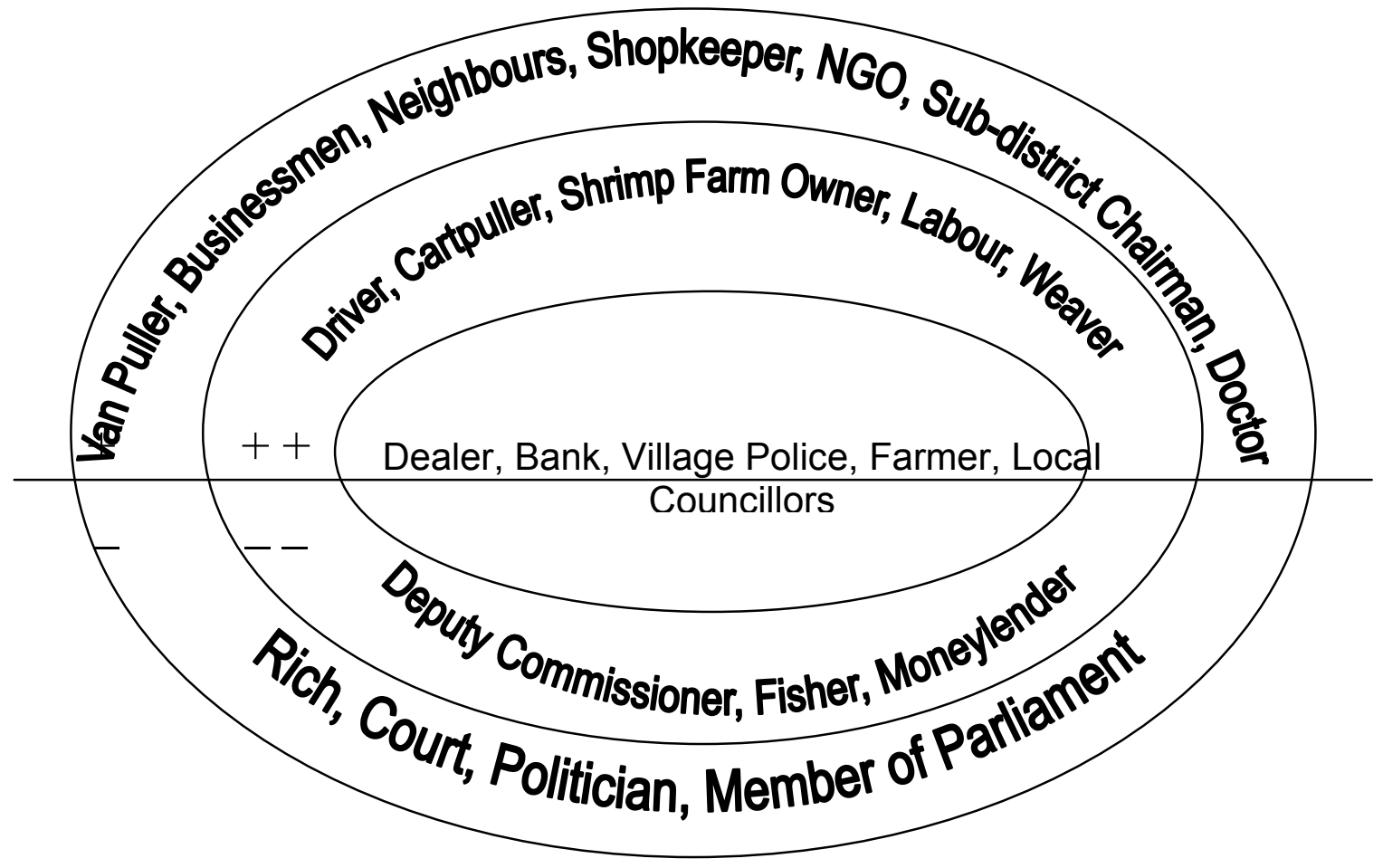


Secondly, a detailed analysis of the actions required for possible solutions is made including the objectives, identification of alternatives in case a solution proves infeasible, their political and social feasibility, technical feasibility, and expected environmental impacts and sustainability (Table 6). Thirdly, an assessment is made of the potential impacts of the solutions on all of the main stakeholders identified thus highlighting feasibility and any critical adverse impacts (Tables 7 and 8).

Table 6--Example of solution analysis for key natural resources problems identified in Vietnam site.

a) Problem: Natural fish declining

\begin{tabular}{|c|c|c|c|c|c|c|}
\hline $\begin{array}{l}\text { Solutions/ } \\
\text { Actions }\end{array}$ & Purpose & Alternative & $\begin{array}{l}\text { Political/ social } \\
\text { impact }\end{array}$ & $\begin{array}{l}\text { Technical/ } \\
\text { economic aspects }\end{array}$ & $\begin{array}{l}\text { Environmental } \\
\text { Impacts }\end{array}$ & Sustainability \\
\hline $\begin{array}{l}\text { Conservation of } \\
\text { fish (fish } \\
\text { sanctuary) }\end{array}$ & $\begin{array}{l}\text {-To increase the } \\
\text { number of fish } \\
\text {-For ecological } \\
\text { balance } \\
\text {-To increase fish } \\
\text { diversity }\end{array}$ & None & $\begin{array}{l}\text { Community } \\
\text { benefit, some } \\
\text { households } \\
\text { will be } \\
\text { affected }\end{array}$ & $\begin{array}{l}\text {-Need technical } \\
\text { support from the } \\
\text { experts }\end{array}$ & Positive impact & Long term \\
\hline $\begin{array}{l}\text { Canal re- } \\
\text { excavation }\end{array}$ & (see below) & & & & & \\
\hline $\begin{array}{l}\text { Integrated Pest } \\
\text { Management } \\
\text { (IPM) }\end{array}$ & $\begin{array}{l}\text {-To reduce pesticide } \\
\text { use and water } \\
\text { pollution (which } \\
\text { affects fish) and } \\
\text { health hazard }\end{array}$ & $\begin{array}{l}\text { Just reduce } \\
\text { use of } \\
\text { pesticide }\end{array}$ & None & $\begin{array}{l}\text {-IPM training } \\
\text { arranged by } \\
\text { CanTho } \\
\text { University and } \\
\text { government } \\
\text { extension agencies }\end{array}$ & Positive impact & $\begin{array}{l}\text { Depend on } \\
\text { awareness } \\
\text { building and } \\
\text { farmers' } \\
\text { reception }\end{array}$ \\
\hline $\begin{array}{l}\text { Changing } \\
\text { agricultural } \\
\text { practices (from } \\
3 \text { paddy crops a } \\
\text { year to } 2 \text { paddy } \\
\text { crop and a } \\
\text { vegetable) }\end{array}$ & $\begin{array}{l}\text {-To increase income } \\
\text {-To improve soil } \\
\text { fertility } \\
\text { - To reduce pesticide } \\
\text { use and water } \\
\text { pollution }\end{array}$ & None & $\begin{array}{l}\text {-More labor } \\
\text { use - will } \\
\text { employ more } \\
\text { local people }\end{array}$ & $\begin{array}{l}\text {-Need } \\
\text { demonstration }\end{array}$ & $\begin{array}{l}\text { Positive impact } \\
\text { due to less use } \\
\text { of pesticide }\end{array}$ & $\begin{array}{l}\text {-Depend on } \\
\text { market } \\
\text { demand }\end{array}$ \\
\hline
\end{tabular}

b) Problem: Canal silted up

\begin{tabular}{|c|c|c|c|c|c|c|}
\hline $\begin{array}{l}\text { Solutions/ } \\
\text { Actions }\end{array}$ & Purpose & Alternative & $\begin{array}{l}\text { Political/ social } \\
\text { impact }\end{array}$ & $\begin{array}{l}\text { Technical/ } \\
\text { economic aspects }\end{array}$ & $\begin{array}{l}\text { Environmental } \\
\text { Impacts }\end{array}$ & Sustainability \\
\hline $\begin{array}{l}\text { Canal re- } \\
\text { excavation }\end{array}$ & $\begin{array}{l}\text {-To improve water } \\
\text { flow } \\
\text {-To increase water } \\
\text { availability for } \\
\text { community use } \\
\text { - To ensure more fish } \\
\text { for food and for sale }\end{array}$ & None & $\begin{array}{l}\text {-Some } \\
\text { households } \\
\text { will be } \\
\text { disturbed by } \\
\text { excavation }\end{array}$ & $\begin{array}{l}\text {-Need technical } \\
\text { support / advice }\end{array}$ & Positive impact & No idea \\
\hline
\end{tabular}


Table 6--Example of solution analysis for key natural resources problems identified in Vietnam site (continued)

\begin{tabular}{|c|c|c|c|c|c|c|}
\hline $\begin{array}{l}\text { Solutions/ } \\
\text { Actions }\end{array}$ & Purpose & Alternative & $\begin{array}{l}\text { Political/ social } \\
\text { impact }\end{array}$ & $\begin{array}{l}\text { Technical/ } \\
\text { economic aspects }\end{array}$ & $\begin{array}{l}\text { Environmental } \\
\text { Impacts }\end{array}$ & Sustainability \\
\hline Sink tubewells & $\begin{array}{l}\text { To get safe water for } \\
\text { domestic purposes } \\
\text { and irrigation }\end{array}$ & $\begin{array}{l}\text { Rainwater } \\
\text { harvest } \\
\text { Storing water } \\
\text { in reservoir }\end{array}$ & None & $\begin{array}{l}\text {-Support from } \\
\text { technical experts }\end{array}$ & $\begin{array}{l}\text { Better quality } \\
\text { water, less } \\
\text { pollution }\end{array}$ & No idea \\
\hline Using biogas & $\begin{array}{l}\text { To use household } \\
\text { waste for biogas } \\
\text { production }\end{array}$ & $\begin{array}{l}\text { - Use waste } \\
\text { for } \\
\text { composting }\end{array}$ & None & $\begin{array}{l}\text {-Support from } \\
\text { technical experts }\end{array}$ & No idea & No idea \\
\hline
\end{tabular}

Source: PAPD workshop

Table 7--Summary of social impact analyses of solutions to the problem of natural fish declining made by stakeholder groups in the Bangladesh site.

\begin{tabular}{|c|c|c|c|c|c|c|c|c|c|c|c|c|c|c|c|c|c|c|}
\hline & \multicolumn{6}{|c|}{$\begin{array}{c}\text { To stop fishing in breeding } \\
\text { period }\end{array}$} & \multicolumn{6}{|c|}{$\begin{array}{l}\text { To preserve brood fish by } \\
\text { establishing sanctuary }\end{array}$} & \multicolumn{6}{|c|}{ To reduce agro-chemical use } \\
\hline Stakeholders & 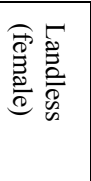 & 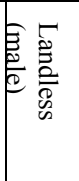 & $\begin{array}{l}\frac{T}{2} \\
\frac{\vec{w}}{2} \\
\frac{9}{6} \\
\frac{5}{2}\end{array}$ & 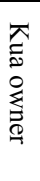 & 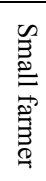 & 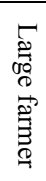 & 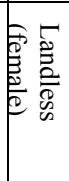 & 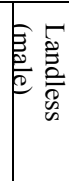 & $\begin{array}{l}\frac{T}{\overrightarrow{0}} \\
\frac{0}{9} \\
\frac{9}{6}\end{array}$ & 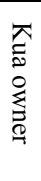 & 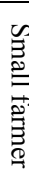 & 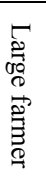 & 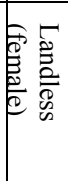 & 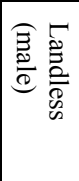 & $\begin{array}{l}\frac{7}{5} \\
\frac{5}{9} \\
\frac{9}{2}\end{array}$ & 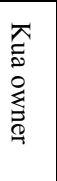 & 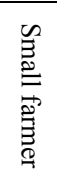 & 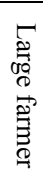 \\
\hline Landless-male & & -+ & + & & + & & - & + & + & & + & & & + & & + & - & + \\
\hline Fisher & & -+ & & + & & + & & + & & + & + & + & & & + & + & + & \\
\hline Kua owner & & + & & & & & & + & & & & & & & & + & & \\
\hline Small farmer & & & & + & + & & & & & + & + & & & & & & & \\
\hline Large farmer & & & & + & & & & + & & + & & & - & - & & + & - & + \\
\hline Fertilizer dealer & & & - & & & & & & & & & & - & & - & - & - & \\
\hline Fish trader & + & -+ & + & + & & & + & + & + & + & & & + & & & + & & \\
\hline Money lender & - & & - & + & & & - & & & + & & & - & & - & & & \\
\hline Local elite & & & - & + & & + & & + & & + & + & + & - & & & & & \\
\hline Local councilors & & & + & & + & + & & & + & & + & + & & & - & & & \\
\hline Sluice gate operator & - & & & + & & & + & - & & & & & & & & & & \\
\hline Gher owner & - & & & & & & - & & & & & & - & & & & & \\
\hline Agriculture Dept & & & + & & + & & & & & & & & & & & & + & + \\
\hline Fisheries Dept & & & + & & + & + & & & + & & + & & & & + & & & \\
\hline NGO & & + & + & & + & + & - & + & & & + & + & & - & - & & + & + \\
\hline $\begin{array}{l}\text { Outsiders who fish } \\
\text { here }\end{array}$ & & - & & & & & - & & & & & & & & & & & \\
\hline
\end{tabular}

Notes: $+=$ positive impact, $-=$ negative impact, $-+=$ both negative and positive impacts, blank $=$ no impact or not assessed

Bold indicates stakeholders considered to be strong negative forces on the lives of poorer stakeholder groups. Not all stakeholder groups in the PAPD identified all of the other stakeholder categories as significant to their livelihoods, for example landless women are involved in collecting snails to sell as feed for the owners of shrimp farms known as gher and believed that the scope to expand and intensify shrimp collection would be reduced by the solutions proposed.

Source: PAPD workshop. 


\section{Table 8--Summary of social impact analyses of solutions to two problems in the Vietnam site (consolidated across stakeholder groups).}

\begin{tabular}{|c|c|c|c|c|c|c|}
\hline \multirow[t]{2}{*}{ Stakeholders } & \multicolumn{4}{|c|}{ Problem 1: Fish declining } & \multicolumn{2}{|c|}{ Problem 3: Water Pollution } \\
\hline & $\begin{array}{l}\text { Conserve } \\
\text { fish }\end{array}$ & $\begin{array}{l}\text { Re-excavate } \\
\text { canal }\end{array}$ & $\begin{array}{l}\text { Applying } \\
\text { IPM }\end{array}$ & $\begin{array}{l}\text { Change } \\
\text { agricultural } \\
\text { practices }\end{array}$ & $\begin{array}{l}\text { Sink } \\
\text { tubewell }\end{array}$ & $\begin{array}{l}\text { Use household } \\
\text { waste as biogas }\end{array}$ \\
\hline Fish trader & + & + & + & + & 0 & 0 \\
\hline Vegetable trader & + & + & + & + & 0 & 0 \\
\hline Mushroom trader & 0 & + & + & - & + & 0 \\
\hline Meat trader & - & + & 0 & 0 & + & + \\
\hline Shop owners & + & + & + & + & + & + \\
\hline Fertilizer/pesticide dealer & + & + & + & + & + & + \\
\hline Gasoline vender & - & + & 0 & + & 0 & 0 \\
\hline Noodle trader & 0 & + & + & 0 & + & 0 \\
\hline Fruit buyer & + & + & - & + & + & + \\
\hline Fish sauce buyer & + & + & + & + & + & + \\
\hline Police & + & + & + & + & + & + \\
\hline Local government & + & + & + & + & + & + \\
\hline
\end{tabular}

Notes: $+=$ positive impact, $-=$ negative impact, $0=$ no impact

Source: PAPD workshop.

The final plenary in this phase is vital for making the links between stakeholder groups and their individual understandings of problems and solutions, and linking the participants and local community's analysis with tiers of administration and government. The outcomes of the individual solution analyses are posted on the walls and mixed groups of participants and secondary stakeholders visit and get explanations of the process and outcomes. In both countries the meetings took place at local government offices and gave an opportunity for local officials to endorse the plans developed by the participants. More importantly this final plenary is the opportunity to find a closure point - if there is a consensus on the feasible solutions and actions required, including identification of a plan that would not adversely affect any critical stakeholders exerting negative forces on the lives of the community and particularly the poorer stakeholders. 


\section{IMPLEMENTATION PHASE}

Theory

The core phase of the PAPD (participatory planning) is envisaged as an empowering process that will build social capital and lead to establishing or adjusting local institutions and organizations for better management of common pool resources. This is based on the concept of establishing community-based management of a form that may be termed 'empowering co-management' (Viswanathan et al. 2002) where the resource users have an active role in setting objectives and creating the knowledge base for resource management and are not just implementing decisions taken by government. Organizational development is needed and there are more detailed decisions to be taken that relate to implementation of the action plan for physical works and for rules and institution development. There may also be a need to resolve local conflicts within the context of an overall consensus or shared view of problems and solutions, and local government agencies play a key role in this. The stages identified in this phase are overlapping and mutually reinforcing and are not necessarily a step-by-step process but involve iterations and feedback as management arrangements are expected to be improved and be adapted over time.

\section{Detailed planning and institution building}

In Vietnam because there had been earlier work by the partner organization and previous participatory analysis, the problem census was in effect a more systematic revalidation of earlier analyses. With a local government (the Village People's Organization) ready to support actions developed and actively involved in the process, in the second round of stakeholder workshops and the final plenary the participants discussed implementation issues in much greater detail than in Bangladesh and in large 
part achieved stages nine and ten. They also voted for stakeholder representatives in the implementation committee. The PAPD workshop was followed up by stage eleven comprising problem solving negotiations (December 2001) immediately before implementation (January 2002). These steps linked the PAPD process to the achievement of a feasible implementation plan. The issues discussed and agreed on covered details of implementation and institutional arrangements and the outcomes were disseminated locally through participant-neighbor contact and upwards through the plenary which also involved higher levels of government above the village people's organization. The issues covered in implementation planning were:

- actions needed to achieve the priority solutions,

- possible conflicts and their mitigation,

- composition of the resource management committee,

- rules to be followed and punishments for non-compliance,

- indicators of success and monitoring to assess impacts, and

- timetable for implementation.

What is notable is that the separate stakeholder groups came up with similar outcomes from this process, and it was then possible in the plenary to consolidate them and reach a general agreement on the plan and institutions required - this combination of organizational changes and norms and rules in fact formed in large part the implementation plan in Vietnam. However, this plan subsequently required modification, as will be seen below. The key points of the action plan developed in Vietnam and the rules agreed upon by the participants were:

- one canal would be excavated to make deeper areas to be designated and marked as a fish sanctuary with signboards and flags posted,

- there would be no fishing at any time in the sanctuary, 
- there would be no boats of any kind allowed to move in the sanctuary canal,

- after three years half of the sanctuary would be fished with income distributed equally among all people living along the sanctuary and Nga Ngay canal,

- measures to reduce water pollution through a reduction in pesticide use and limits on duck rearing in the canal

Additional rules agreed for the neighboring Nga Ngay canal comprised:

- no fishing using electricity or dynamite,

- no use of chemicals to attract fish,

- fishing nets with mesh size smaller than $2.5-3 \mathrm{~cm}$ would not be permitted,

- fish under $3 \mathrm{~cm}$ in length (juveniles) cannot be caught,

- no big boats (including tourist boats) or engine boats to move along the canal, and

- ducks should not be raised in either the sanctuary or Nga Ngay canals and should not be used for fishing (a local practice regarded as harmful by the participants).

The various stakeholder groups set sanctions for rule violators (each successive group saw the proposed rules from the preceding group sessions, amended or modified them, and final discussion occurred in the plenary) :

$1^{\text {st }}$ time violation: the hamlet head will explain to the violator the rules and their importance and will arrange awareness training

$2^{\text {nd }}$ time violation: a fine of ten times the value of the caught fish to be paid to the committee by the offender (but twenty times the value if a member of the people's organization or administration breaks the rules)

$3^{\text {rd }}$ time violation: hand the violator over to the law enforcing authority

It was also agreed to form a project management committee to implement the plan comprising nine members: five members from the local People's Organization, and one member from each of the four stakeholder categories that were represented in the 
workshop. Furthermore the stakeholder groups also reviewed the expected outputs of their action plan, and identified indicators for these impacts and how they could be assessed through participatory monitoring, this is shown in Table 9.

Table 9--Indicators and participatory monitoring arrangements agreed through PAPD by the community in Vietnam

\begin{tabular}{|c|c|c|}
\hline Indicator/output & Type of monitoring & Responsibility \\
\hline Fish catch increase & Catch & five people agreed to record their fish \\
\hline Fish diversity increase & Catch & $\begin{array}{l}\text { catches with advice from research } \\
\text { team }\end{array}$ \\
\hline Fish consumption increase & Consumption & $\begin{array}{l}30 \text { households agreed to monitor } \\
\text { their own fish consumption and catch }\end{array}$ \\
\hline Increase in fish marketed & Market survey & People's Organization \\
\hline Reduced use of pesticide & $\begin{array}{l}\text { Training and adoption of integrated } \\
\text { pest management }\end{array}$ & CTU \\
\hline Safer domestic water & water quality & CTU \\
\hline Better habitat for fish & water quality & \\
\hline Increased income from 'VAC' & demonstration plots/uptake & CTU/People's Organization \\
\hline More sustainable agriculture & demonstration plots/uptake & \\
\hline
\end{tabular}

Notes: CTU = Can Tho University; 'VAC' is the Vietnamese abbreviation for vuon, ao, chuong meaning integrated farming of "garden" (crops and orchards), pond (fish) and livestock.

Source: PAPD workshop.

\section{CONFLICT RESOLUTION}

After detailed planning (stage ten), the individual interest groups reviewed the plans. Seventeen households raised specific concerns, these came from eight duck raisers, two canal-side tree owners, and seven people owning land by the side of the sanctuary canal. They anticipated negative impacts from re-excavation or specific rules, although they agreed with the problems facing the community and the appropriateness of the solutions in general. The process adopted was based on facilitated negotiations through problem identification and alternate solution analysis on an individual basis, with solutions coming from the community leaders and from the People's Committee. For example, the People's Committee agreed that anyone found to have their land adversely affected would be exempt from paying local taxes for three years, specific alternative livelihood activities and sources of help were identified for those dependent on duck 
rearing, and dredging spoil was used for a local path to avoid effects on farm land. In this way the common consensus on overall measures and benefits was retained and an ownership process even among people who were skeptical of the plan was built-in through the adaptive nature of the action-research participatory planning process. This highlights the need for action-researchers not to leave once a participatory action plan has been developed, but also to be on hand to help the institutions (in this case both old People's Committee, and new - project management committee) work together with the community members to find viable solutions.

\section{PROCESS ASSESSMENT}

Institutional and impact monitoring and feedback are undertaken as part of the ongoing process, in Vietnam through the arrangements developed with the community in the PAPD, and in Bangladesh through an on-going project that will also support plan implementation by the community. Moreover, a matched random sample survey of PAPD participants and non-participants in each case study was built into the testing of the PAPD approach. In Bangladesh the PAPD participants and control samples for four stakeholder groups (landless men and women, fishers, and large farmers) were surveyed about three weeks before and three weeks after the PAPD. In Vietnam a similar survey was conducted before the PAPD workshop, and the repeat survey was conducted in April 2002 after the committee implemented the first parts of its plan (re-excavation of the canal and establishment of the sanctuary and fishing and water use rules). The survey used statements and scales to assess cognitive social capital (including any changes), it also determined which dimensions of cognitive social capital were most relevant to the concept of consensus in the participants' own views, and asked directly for views on the 
PAPD process and any apparent changes. Here we summarize some of the results from the analysis. Given the timing of the surveys it was expected that in Vietnam the impact would be greater because implementation was well under way and respondents /participants could see the results of their planning, and this appeared to be true.

When asked directly in the post-PAPD survey if they had noticed changes since the PAPD in trust, cooperation, unity and willingness to work for the common good of the community, almost all participants in Vietnam (who had seen the initial actions and solutions of the plan they had prepared implemented) reported an improvement in cooperation, unity and working for the common good (Fig. 4a).

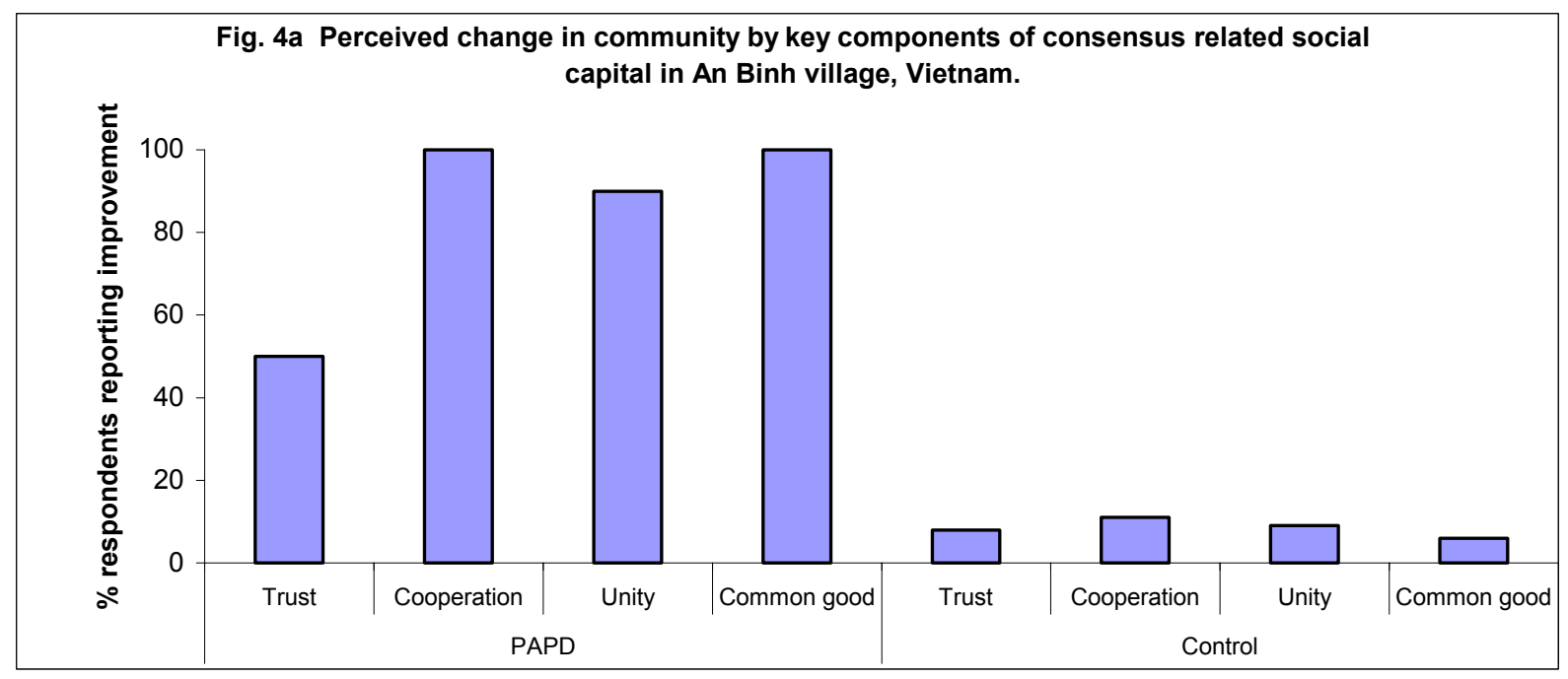

Trust had not changed so much and this is because the participants say they are observing whether the attitude of the People's Organization has really changed. However, very few of the control group reported any change - these respondents were from a neighboring village that was not directly involved in the process. By comparison in the Bangladesh case the majority of PAPD participants (but smaller percentage compared to 
Vietnam) reported an improvement in these indicators after the PAPD (Fig. 4b). This probably reflects already high levels of social capital in a rather homogeneous community where there are already high levels of trust, although there were improvements apparent in repeat surveys (for example in the likelihood that fishers would fish as a team to achieve a higher return per person - trust - after the PAPD).

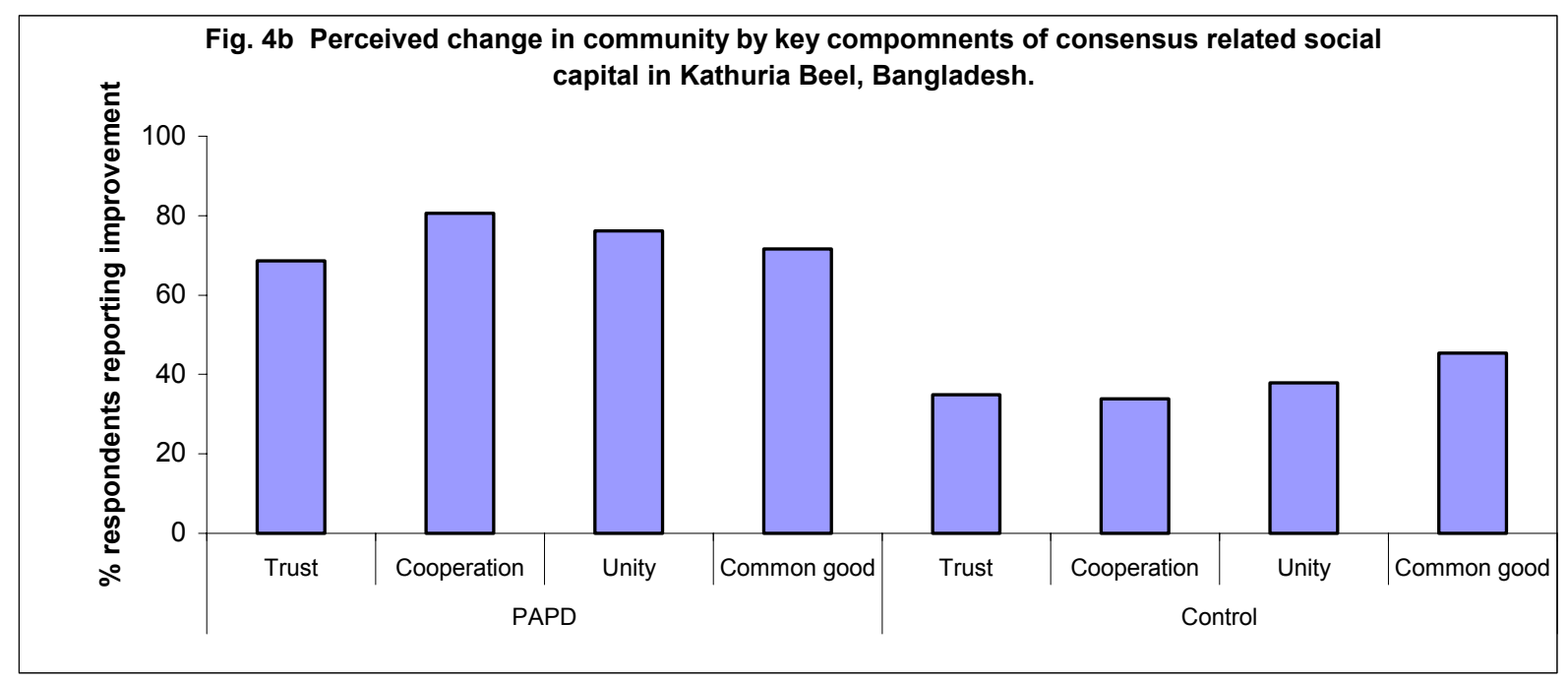

About 60 per cent of non-PAPD participants in Bangladesh had heard about the process and workshops (since they were from the same villages and were neighbors of the participants). Virtually all of the participants thought it had been useful and rated it highly and most non-participants who had heard about it also rated it highly but with a wider spread of scores. They mainly reported benefits from the PAPD in terms of understanding of issues and knowledge, but over 30 per cent of non-participants claimed that they could see changes in community attitudes related to social capital.

A series of statements with seven-point scales of agreement of disagreement were used in the pre- and post- PAPD surveys to attempt to measure indicators of social capital. In general few statistically significant changes in the indicators were reported 
from the before-after comparison. However, the incidence of above mid-point scores in these scales (Fig. 5) indicates that the participants in the Vietnam site, with an apparently more homogeneous community in economic terms but more individualistic in activities, tended to give lower ratings before the PAPD and on average gave higher scores (mostly above the mid-points) after the PAPD, compared with the Bangladesh site, where there was little difference between the two surveys in responses to the scales, but cooperation, unity, etc. were already at high levels.

In Vietnam engagement in negotiation and conflict resolution in the community was apparently low before the PAPD, but after successfully solving existing conflicts and observing fruitful negotiations respecting both individual and collective interests, the participants were confident that conflict resolution had improved. A somewhat different indicator is the perceived likelihood of creating a community fish sanctuary is. The creation of the sanctuary was raised and discussed in the communities before the PAPD, in Vietnam through previous PRAs and in Bangladesh because the villagers using a neighboring area of floodplain had already established small sanctuaries.

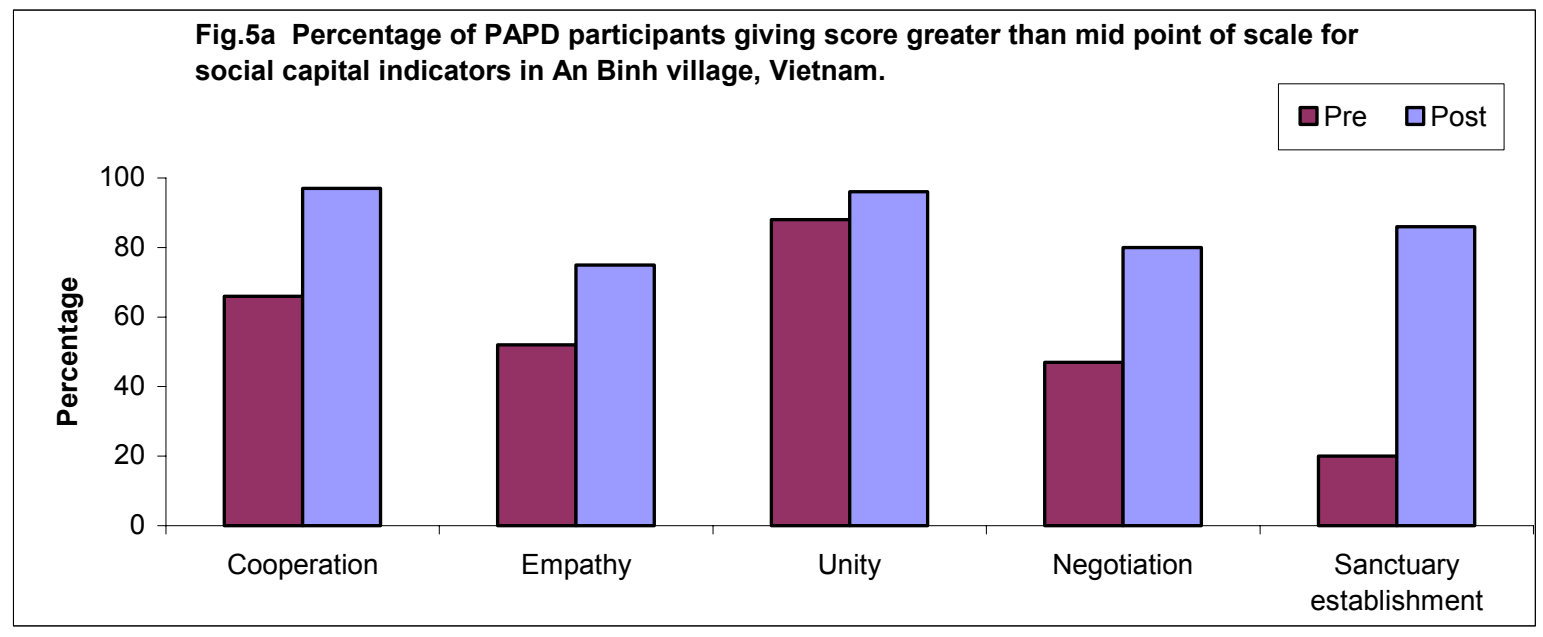




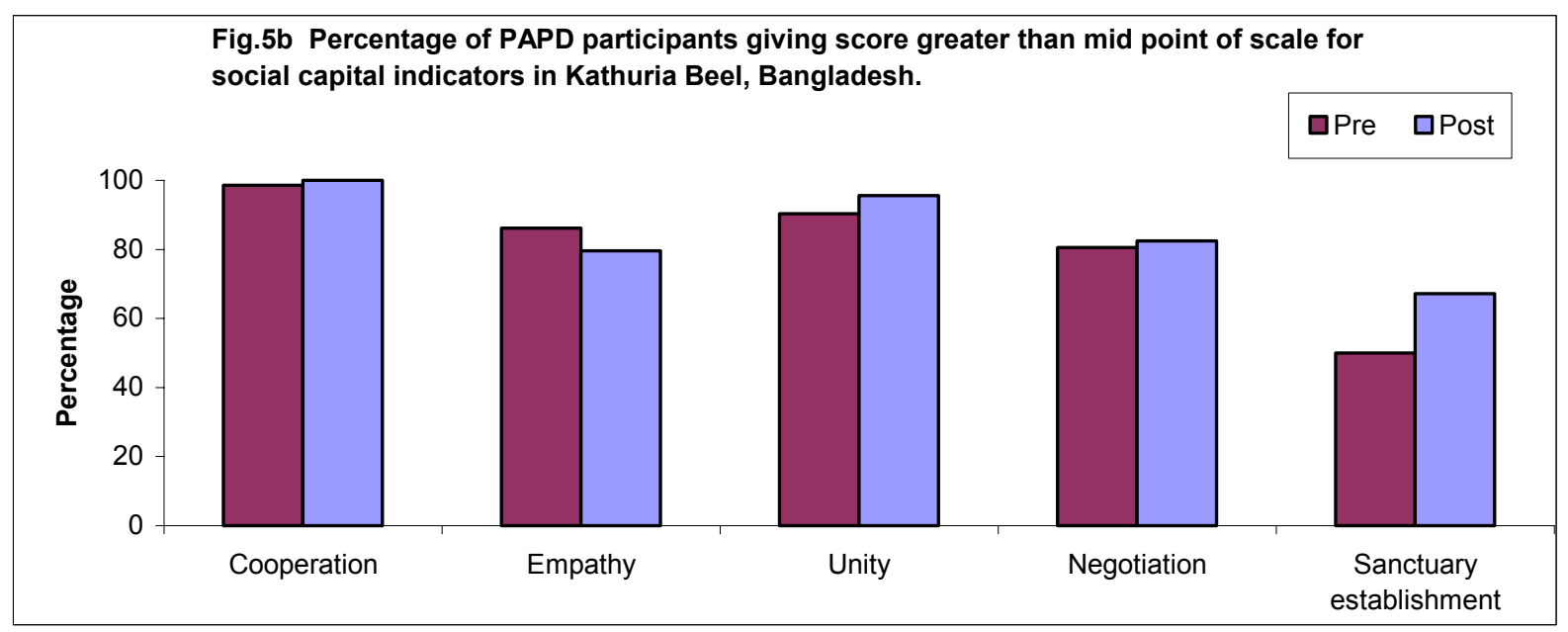

The sanctuary was one of the selected solutions in both sites, and it is therefore not surprising that the percentage of people believing that one would be established increased in both sites. In Vietnam, as excavation was completed, over 80 percent of participants thought that the rules they had agreed on would be adopted.

The respondents were also asked in both pre- and post- PAPD surveys what concepts they thought were the most important components of what they understood by 'consensus'. The participants agreed that the concepts related to consensus used in the survey were important, but ratings differed across sites. In Bangladesh the concepts were on average rated as more important than in Vietnam, where PAPD participants gave notably low ratings on the importance of any of the concepts related to consensus. But in Vietnam for most concepts participants significantly changed their views following the PAPD (Table 10), whereas there was no change for the control sample and virtually no change for either participants or control sample in the Bangladesh case. With respect to empowerment, it is considered an important part of the consensus, but participants felt that as they did not have financial power there empowerment was not complete. 
Nonetheless they believed that their decisions were valued during the planning process.

Changes in opinion about the importance of cooperation, negotiation and the common good after building consensus through PAPD appear to be linked to the process. In summary indicators of cognitive social capital do change as a results of participation in the PAPD process, particularly when this results into collective actions. The indicators used do appear to be relevant ones, but the ranking in importance differs between the two countries and this appears to be due to different local cultures and past social experiences.

Table 10--Respondent's assessments (mean scores) of the importance of social capital concepts to their understanding of "consensus"

a) An Binh, Vietnam

\begin{tabular}{lcccccc}
\hline Social capital & \multicolumn{3}{c}{ PAPD } & & \multicolumn{3}{c}{ Control } \\
\cline { 2 - 7 } Indicator & Pre & Post & Significance & Pre & Post & Significance \\
\hline Trust & 1.7 & 2.0 & $*$ & 2.1 & 2.1 & $\mathrm{~ns}$ \\
Harmony & 1.8 & 2.0 & $*$ & 2.0 & 2.0 & $\mathrm{~ns}$ \\
Empowerment & 2.3 & 2.6 & $\mathrm{~ns}$ & 2.6 & 2.6 & $\mathrm{~ns}$ \\
Cooperation & 1.3 & 2.1 & $* *$ & 2.1 & 2.1 & $\mathrm{~ns}$ \\
Empathy & 1.5 & 2.1 & $\mathrm{~ns}$ & 2.1 & 2.1 & $\mathrm{~ns}$ \\
Unity & 1.3 & 1.4 & $\mathrm{~ns}$ & 2.0 & 2.0 & $\mathrm{~ns}$ \\
Negotiation & 1.3 & 2.2 & $* *$ & 2.9 & 3.0 & $\mathrm{~ns}$ \\
Common good & 1.1 & 3.4 & $* *$ & 3.4 & 3.8 & $\mathrm{~ns}$ \\
\hline
\end{tabular}

b) Kathuria Beel, Bangladesh

\begin{tabular}{lcccccc}
\hline Social capital & \multicolumn{3}{c}{ PAPD } & & \multicolumn{3}{c}{ Control } \\
\cline { 2 - 7 } indicator & Pre & Post & Significance & Pre & Post & Significance \\
\hline Trust & 3.3 & 3.2 & $\mathrm{~ns}$ & 3.4 & 3.3 & $\mathrm{~ns}$ \\
Harmony & 3.1 & 3.2 & $\mathrm{~ns}$ & 3.0 & 3.2 & $\mathrm{~ns}$ \\
Empowerment & 2.9 & 2.7 & $*$ & 2.9 & 2.6 & $* *$ \\
Cooperation & 3.2 & 3.2 & $\mathrm{~ns}$ & 3.2 & 3.3 & $\mathrm{~ns}$ \\
Empathy & 2.8 & 2.7 & $\mathrm{~ns}$ & 2.8 & 2.9 & $\mathrm{~ns}$ \\
Unity & 3.8 & 3.8 & $\mathrm{~ns}$ & 3.9 & 3.8 & $\mathrm{~ns}$ \\
Negotiation & 2.7 & 2.5 & $\mathrm{~ns}$ & 2.6 & 2.6 & $\mathrm{~ns}$ \\
Common good & 3.4 & 3.3 & $\mathrm{~ns}$ & 3.2 & 3.3 & $\mathrm{~ns}$ \\
\hline
\end{tabular}

Notes: categories were ranked as: $4=$ very important, $3=$ important, , $2=$ "so-so", $1=$ not important Significance is by Wilcoxon signed-rank test, ${ }^{* *} \mathrm{p}<0.05,{ }^{*} \mathrm{p}<0.1$

Indicators in bold are the four in each study area that overall appear to have been considered by respondents to be the most important components of 'consensus'.

Source: pre- and post-PAPD surveys. 


\section{CONCLUSIONS}

The process presented in this paper is based on experience in Bangladesh that consensus building among all stakeholder groups in the communities that use and benefit from wetland resources is an essential element of collective action and development of co-management institutions. Surveys of participants before and after the core phase of the PAPD process assessed that opinions and some indicators of social capital displayed significant changes. In the Vietnam case local consensus building outcomes were validated with the local, district and provincial government authorities in the plenary workshop, and several actions in the plan have been successfully implemented by the community and the local government.

We conclude that the PAPD approach is an effective way of achieving participatory planning and developing collective action for natural resource management at the local level. The structure of the process ensures that all stakeholder groups are involved, their voices are heard and that it does not rely on self-selected spokespersons. It also enables people from each stakeholder group to understand each other's problems and aspirations, to find common interests, and to identify win-win solutions. This appears to be a good starting point for community-led resource management interventions and for developing local institutions.

This approach does appear to be transferable from Bangladesh to other social settings, based on experience in Vietnam. However, it is not a way to resolve fundamental conflicts, e.g. regarding access to resources. Application in Vietnam showed the need to add to the process a stage where individual stakeholders (including those who were not directly involved in the PAPD) can reflect on the outcomes and proposed action 
plans and where they can investigate and negotiate, with the local community leaders, adjustments to the implementation plans that minimize any short term adverse individual impact. These experiences confirm that ultimately all parties recognized that there were wider social benefits and that the whole community would gain from working together.

This method has now been adopted in several projects working in wetland and fishery management in Bangladesh, and there is interest among the NGO community to apply it more widely. In addition adjacent communities have shown interest in taking up similar practices and processes. PAPD does require an initial intensive input from external agents. Learning about the community and undertaking the census (phase one) can take a week for a small team in a typical wetland-community area. To conduct the PAPD core (phase two) for six stakeholder groups with two skilled facilitators and four helpers requires an eight day workshop. Last, but most importantly, there must be a long term but intermittent commitment in phase three to advise and help developing and adapting local institutions, helping the community resolve conflicts, and developing detailed plans and their implementation. Similarly the community investment in time is substantial. Although most individual participants invest only two days in the workshop, in total participants invest about 260 person-days in phase two in a typical PAPD, less with fewer stakeholder categories. Thereafter the investment in time is higher for the members of any committee or management group formed, but also spreads to the wider community through general meetings and mitigation planning. However, there is a great potential benefit from these investments. Collective action, which is outside the scope of single individuals, can be taken up, and results in common shared improvements in resource base and use. There are also long-term gains in social capital - trust, 
cooperation, social cohesion - leadership development, ownership by the community, especially among the poorer members, as well as in wetland resources health. 


\section{REFERENCES}

Agarwal, A. 2001. Common property institutions and sustainable governance of resources. World Development 29(10): 1649-72.

Allen, W., O. Bosch, M. Kilvingon, J. Oliver and M. Gilbert. 2001. Benefits of collaborative learning for environmental management: Applying integrated systems for knowledge management approach to support animal pest control. Environmental Management 27(2): 215-223.

Bain, K. and N. Hicks. 1998. Building social capital and reaching out to excluded groups: The challenge of partnerships. Paper presented at Consejo Episcopal Latinoamericano (CELAM) meeting on The struggle against poverty towards the turn of the millennium, Washington, DC.

Barr, J.J.F. 1998. Systems approaches in research and extension on Bangladesh floodplains Rural Extension Bulletin 12: 44-47.

Barr, J.J.F, P-J. Dixon, M.M. Rahman, M.A. Islam, M.I. Zuberi, A.A. McGlynn, and G.P. Ghosh. 2000. A participatory, systems-based, process for identification of improved natural resources management for better floodplain livelihoods. Project report of R6756. Newcastle, England: University of Newcastle, Centre for Land Use and Water Resources Research.

Barr, J.J.F. and P-J. Dixon. 2001. Methods for consensus building for management of common property resources. Final Technical Report of R7562. Newcastle, England: University of Newcastle, Centre for Land Use and Water Resources Research.

Berkes, F., D. Feeny, B.J. McCay, and J.M. Acheson. 1989. The benefits of the Commons', Nature 340: 91-93.

Carney, D. 1998. Implementing the sustainable rural livelihoods approach. In Sustainable rural livelihoods what contribution can we make? ed, D. Carney. London: Department for International Development.

Edmunds, D. and E. Wollenberg. 2001. A strategic approach to multistakeholder negotiations. Development and Change 32(2): 231-53.

Holmes, T. and I. Scoones. 2000. Participatory policy processes: Experiences from North and South. IDS Working Paper 113. Brighton: Institute of Development Studies.

Kaner, S. 1996. Facilitator's guide to participatory decision making. British Columbia: New Society Publishers; San Francisco: Community at Work. 
Krishna, A. and E. Shrader. 1999. Social capital assessment tool. Paper presented at the Conference on Social Capital and Poverty Reduction, World Bank, Washington, D.C. (22-24 June).

Krishna, A. and N. Uphoff. 1999. Mapping and measuring social capital: A conceptual and empirical study of collective action for conserving watersheds in Rajasthan, India. Social Capital Initiative Working Paper no. 13. Washington, DC: Environmentally and Socially Sustainable Development Network, World Bank.

McCool, S.F. and K. Guthrie. 2001. Mapping the dimensions of successful public participation in messy natural resources management situations. Society and Natural Resources 14: 309-323.

Middendorp, A.J., P.M. Thompson and R.S. Pomeroy (eds.). 1999. Sustainable inland fisheries management in Bangladesh. ICLARM Conference Proceedings 58. Manila: International Center for Living Aquatic Resources Management.

Mosse, D. 1994. Authority, gender and knowledge: theoretical reflections on the practice of Participatory Rural Appraisal. Development and Change 25(3): 497-526.

Ostrom, E. 1990. Governing the Commons: The evolution of institutions for collective action. Cambridge, UK and and New York: Cambridge University Press.

Ostrom, E. 1994. Institutional analysis, design principles and threats to sustainable community governance and management of Commons. In community management and common property of coastal fisheries in Asia and the pacific: concepts, methods and experiences, ed. R.S. Pomeroy. ICLARM Conference Proceedings 45, Manila: ICLARM.

Pomeroy, R.S. 1998. A process for community-based fisheries co-management. NAGA the ICLARM Quarterly 21(1): 71-75.

Pomeroy, R.S. and F. Berkes. 1997. Two to tango: The role of government in fisheries comanagement. Marine Policy 21(5): 465-80.

Ravnborg, H.M. and O. Westermann. 2000. Understanding interdependencies: A precondition to collective natural resource management. Paper presented at the Eighth Conference of the International Association for the Study of Common Property, Bloomington, Indiana, May 31-June 4.

Thompson, P.M., P. Sultana, M.N. Islam, M.M. Kabir, M.M. Hossain, and M.S. Kabir. 1999. An Assessment of co-management arrangements developed by the community based fisheries management project in Bangladesh. Paper presented at the International Workshop on Fisheries Co-management, Penang, Malaysia, August 23-28.

Thompson, P.M., P. Sultana, N. Islam, S.M. Nazmul Islam, M.M. Hossain, and A.K. Saha. 2001. Lessons from community based management of floodplain fisheries 
in Bangladesh. Paper presented at the Asian Wetlands Symposium 2001, City Bayview Hotel, Penang, Malaysia. August 27-30.

Viswanathan, K., J.R. Nielsen, P. Degnbol and M. Ahmed. 2002. Fisheries comanagement - an institutional innovation: perspectives and challenges ahead. Penang: ICLARM-The World Fish Center. 


\section{LIST OF CAPRi WORKING PAPERS}

01 Property Rights, Collective Action and Technologies for Natural Resource

Management: A Conceptual Framework, by Anna Knox, Ruth Meinzen-Dick, and Peter Hazell, October 1998.

02 Assessing the Relationships Between Property Rights and Technology Adoption in Smallholder Agriculture: A Review of Issues and Empirical Methods, by Frank Place and Brent Swallow, April 2000.

03 Impact of Land Tenure and Socioeconomic Factors on Mountain Terrace Maintenance in Yemen, by A. Aw-Hassan, M. Alsanabani and A. Bamatraf, July 2000.

04 Land Tenurial Systems and the Adoption of a Mucuna Planted Fallow in the Derived Savannas of West Africa, by Victor M. Manyong and Victorin A. Houndékon, July 2000 .

05 Collective Action in Space: Assessing How Collective Action Varies Across an African Landscape, by Brent M. Swallow, Justine Wangila, Woudyalew Mulatu, Onyango Okello, and Nancy McCarthy, July 2000.

06 Land Tenure and the Adoption of Agricultural Technology in Haiti, by Glenn R. Smucker, T. Anderson White, and Michael Bannister, October 2000.

07 Collective Action in Ant Control, by Helle Munk Ravnborg, Ana Milena de la Cruz, María Del Pilar Guerrero, and Olaf Westermann, October 2000.

08 CAPRi Technical Workshop on Watershed Management Institutions: A Summary Paper, by Anna Knox and Subodh Gupta, October 2000.

09 The Role of Tenure in the Management of Trees at the Community Level:

Theoretical and Empirical Analyses from Uganda and Malawi, by Frank Place and Keijiro Otsuka November 2000.

10 Collective Action and the Intensification of Cattle-Feeding Techniques a Village Case Study in Kenya's Coast Province, by Kimberly Swallow, November 2000.

11 Collective Action, Property Rights, and Devolution of Natural Resource Management: Exchange of Knowledge and Implications for Policy, by Anna Knox and Ruth MeinzenDick, January 2001. 
12 Land Dispute Resolution in Mozambique: Evidence and Institutions of Agroforestry Technology Adoption, by John Unruh, January 2001.

13 Between Market Failure, Policy Failure, and "Community Failure": Property Rights, Crop-Livestock Conflicts and the Adoption of Sustainable Land Use Practices in the Dry Area of Sri Lanka, by Regina Birner and Hasantha Gunaweera, March 2001.

14 Land Inheritance and Schooling in Matrilineal Societies: Evidence from Sumatra, by Agnes Quisumbing and Keijuro Otsuka, May 2001.

15 Tribes, State, and Technology Adoption in Arid Land Management, Syria, by Rae, J, Arab, G., Nordblom, T., Jani, K., and Gintzburger, G., June 2001.

16 The Effects of Scales, Flows, and Filters on Property Rights and Collective Action in Watershed Management, by Brent M. Swallow, Dennis P. Garrity, and Meine van Noordwijk, July 2001.

17 Evaluating Watershed Management Projects, by John Kerr and Kimberly Chung, August 2001.

18 Rethinking Rehabilitation: Socio-Ecology of Tanks and Water Harvesting in Rajasthan, North-West India, by Tushaar Shah and K.V.Raju, September 2001.

19 User Participation in Watershed Management and Research, by Nancy Johnson, Helle Munk Ravnborg, Olaf Westermann, and Kirsten Probst, September 2001.

20 Collective Action for Water Harvesting Irrigation in the Lerman-Chapala Basin, Mexico, by Christopher A. Scott and Paul Silva-Ochoa, October 2001.

21 Land Redistribution, Tenure Insecurity, and Intensity of Production: A Study of Farm Households in Southern Ethiopia, by Stein Holden and Hailu Yohannes, October 2001.

22 Legal Pluralism and Dynamic Property Rights, by Ruth Meinzen-Dick and Rajendra Pradhan, January 2002.

23 International Conference on Policy and Institutional Options for the Management of Rangelands in Dry Areas, by Tidiane Ngaido, Nancy McCarthy, and Monica Di Gregorio, January 2002.

24 Climatic Variablity and Cooperation in Rangeland Management: A Case Study From Niger, by Nancy McCarthy and Jean-Paul Vanderlinden, September 2002. 
25 Assessing the Factors Underlying the Differences in Group Performance:

Methodological Issues and Empirical Findings from the Highlands of Central Kenya, by Frank Place, Gatarwa Kariuki, Justine Wangila, Patti Kristjanson, Adolf Makauki, and Jessica Ndubi, November 2002.

26 The Importance of Social Capital in Colombian Rural Agro-Enterprises, by Nancy Johnson, Ruth Suarez, and Mark Lundy, November 2002.

27 Cooperation, Collective Action and Natural Resources Management in Burkina Faso: A Methodological Note, by Nancy McCarthy, Céline Dutilly-Diané, and Boureima Drabo, December 2002.

28 Understanding, Measuring and Utilizing Social Capital: Clarifying Concepts and Presenting a Field Application from India, by Anirudh Krishna, January 2003.

29 In Pursuit Of Comparable Concepts And Data, About Collective Action, by Amy Poteete And Elinor Ostrom, March 2003. 